\title{
Effect of Stormwater System on the Receiver
}

\author{
Roman Babko', Joanna Szulżyk-Cieplak'2, Yaroslav Danko, \\ Sylwia Duda', Marina Kirichenko-Babko', Grzegorz Łagód ${ }^{5}$
}

\author{
1 Schmalhausen Institute of Zoology NAS of Ukraine, B. Khmelnitsky Str. 15, 01030 Kyiv, Ukraine \\ 2 Lublin University of Technology, Faculty of Fundamentals of Technology, Nadbystrzycka 38, 20-618 Lublin, \\ Poland \\ 3 Sumy Makarenko State Pedagogical University, Romenska, 87, 40002 Sumy, Ukraine \\ 4 Institute of Agrophysics, Polish Academy of Sciences, Doświadczalna 4, 20-290 Lublin, Poland \\ 5 Lublin University of Technology, Faculty of Environmental Engineering, Nadbystrzycka 40B, 20-618 Lublin, \\ Poland \\ * Corresponding author's e-mail: j.szulzyk-cieplak@pollub.pl
}

\begin{abstract}
The surface water quality assessment could be based on a combined physical and chemical analysis, but it could also be determined with bioindication methods. Classical physicochemical analysis is in most cases more expensive and time-consuming than the bioindication methods. This type of analysis also requires expensive equipment and shows the situation in the water only at the moment of sampling. Although the bioindication methods are often complicated, they allow a relatively inexpensive estimation of the water quality. Moreover, during their implementation, the substances harmful to the environment are not generated, and the obtained results usually reflect the total interaction of all factors and substances to the analyzed living organisms. Indicator organisms or their communities applied to the research, with identified ranges of tolerance to selected factors, could help to determine the physical and chemical parameters of water. This paper presents a bioindication study with an effect of stormwater system on the receiver - the Bystrzyca river, in Lublin, Poland. The level of saprophyty of the river sector was calculated based on the selected species of algae (diatoms and green algae) and the influence of the stormwater discharge on the communities of these organisms was determined.
\end{abstract}

Keywords: surface water quality, stormwater, bioindication, algae, saprobity

\section{INTRODUCTION}

The different types of sewage from point and dispersed sources have impact on the majority of water bodies. The intensifying anthropogenic pressure increases the amount of allochthone substances transported with sewage [Babko et al. 2016]. It changes the conditions of existence of protozoa, bacteria [Wakelin et al. 2008] and fosters other microorganisms; as a result, nutrients are provided for numerous invertebrate species [Gücker et al. 2006]. Wastewater discharge points cause pollutant accumulation and reduce the resistance of aquatic ecosystems [Gücker et al. 2006]. Discharging sewage to a river frequently contributes to the processes that lead to a reduction of the dissolved oxygen content or local anoxia [Spänhoff, et al. 2007, Wakelin et al. 2008, Pliashechnyk et al. 2018]. Usually, the trophic status of reservoirs changes locally under the influence of influent wastewater [Smith et al. 1999]. This, in turn, changes the aquatic biocenosis [Wright et al. 1995, Kominkova et al. 2005, Carter et al. 2006, Gorzel and Kornijow 2007].

Environmental monitoring consists in assessments, studies and forecasts of the condition of natural or artificial environment, which may then be used for localizing, preventive and remediatory actions as well as aiding in the decision-making process. Its main function involves acquiring the information on various pollutants, determining the unfavorable changes occurring in 
the environment, evaluating their extent, as well as observing the reaction of living organisms to these changes and pollutants.

Assessment of the quality of still and flowing waters, including both natural and anthropogenic watercourses, can be carried out on the bases of two main methods. The first involves the analysis of the results pertaining to physicochemical studies of water samples collected from conclusive and characteristic points. In turn, the other method is based on determining the water quality using bioindication techniques. The physicochemical analysis is usually relatively expensive and time-consuming; it also often requires costly equipment. This type of analysis shows the situation and conditions in water only at the moment of sample collection. Biological monitoring is often considered as supplement of chemical monitoring. However, it should be noted that chemical monitoring does not ensure complete control of the environment state due to the diversification of pollutants and the related difficulties connected with their investigation. Biomonitoring involves cyclic observations and studies of the reaction of indicator organisms or assemblage structure to the changes in the natural environment in order to evaluate this environment as well as its properties and characteristics [Gorzel and Kornijow 2007; Babko et al. 2016; Gorzel et al. 2018].

The biotic indices usually are sensitive to organic pollutants [Gray and Delaney 2010]. Saprobity is a sum of all organic matter decomposition processes and an indicator providing information on water purity [Libudzisz et al. 2007]. Bioindication employs indicator organisms, on the basis of the presence or absence of which water quality can be determined. [Sladeczek, Iliopoulou-Georgudaki et al. 2003, Łagód et al. 2007, Chomczyńska et al. 2009]. Good bioindicators are characterized by the following properties: short life, enabling adaptation to short-term changes in the environment, abundance and ease of sample collection for analyses, sedentary nature, specific range of response to particular ecosystem changes [Desrosiers et al. 2013, Li et al. 2010].

Although the bioindication methods are also time-consuming and complex, they enable a relatively inexpensive assessment of the aquatic environment condition. The obtained results usually reflect the total impact of all substances and factors that are detrimental to living organisms. The saprobity value increases along with water pollution. It can be determined on the basis of observations and investigations of indicator organisms which were distinguished in particular saprobic zones with assigned saprobity values [Kolkwitz and Marsson 1908, Kolkwitz and Marsson 1909, Kolkwitz 1950]. It enables to classify a given water body to a specific class of water purity. Various organisms are used as indicators [Sladeček 1973, Wright et al., 1995, IliopoulouGeorgudaki et al., 2003, Żbikowski et al. 2007].

Algae are often used as bioindicators, due to their presence in various waters and relative ease of identification. They enable biological evaluation of water quality as well as reflect the physicochemical changes in the conditions occurring in aquatic ecosystems. The response of individual species and entire assemblages to different factors, e.g. heavy metals, $\mathrm{pH}$, nutrients and other physicochemical parameters indicates the condition of the environment [Lane and Brown 2007, Żbikowski et al. 2007, Desrosiers et al. 2013].

\section{MATERIALS AND METHODS}

The biofilm samples from the Bystrzyca river were collected in the summer months. The Bystrzyca river is one of the largest rivers of the Lublin city. Its tributaries include Krężniczanka (west), Czerniejówka (South) and Czechówka (North-east). The total catchment area of Bystrzyca amounts to $1315.5 \mathrm{~km}^{2}$, while its total length equals $74 \mathrm{~km}$, out of which $22.5 \mathrm{~km}$ is found within the city limits. The river pollution was allocated to III and IV water purity class [Adamiec 2008].

The collection of biofilm samples was carried out in three locations which were spread $0.5 \mathrm{~km}$ apart: 1 - before the stormwater inflow, 2 - at the stormwater outflow, 3 - at the full mixing location of river water and stormwater. The samples were taken using a metal blade from submerged concrete slabs. The study material was detached using a cover slip and placed in $250 \mathrm{ml}$ plastic bottles filled with the water from a given point to the half of their capacity. The collected biological material was taken to the laboratory at the Faculty of Environmental Engineering of Lublin University of Technology, in vivo preparations were produced from each sample and observed using bright-field microscopy.

Saprobity were calculated on the basis of the abundance of 12 algae species [Kolkwitz and Marsson 1908, Kolkwitz and Marsson 1909, 
Kolkwitz 1950, Sladeček 1973], presented in Table 1 . Saprobity was calculated using the Pantlie and Buka system and formula [Pantle and Buck 1955; Pantle 1956], as modified by Konstantinov [Konstantinov 1979]:

$$
S=\frac{\sum s_{i} \cdot h_{i}}{\sum h_{i}}
$$

where: $S$ - saprobity,

$s_{i}$ - value of saprophyty of $i$-th species,

$h_{i}-$ abundance of $i$-th species.

The data on the abundances of species were processed using R Version 3.6.0 [R Core Team 2019]. In order to assess the significance of pairwise differences between points analysis of variance (ANOVA) and post-hoc Tukey HSD (Honestly Significant Difference) test was performed with functions aov and TukeyHSD, respectively, in the R package stats. Plots were produced with the R package ggplot2 [Wickham 2009].

\section{RESULTS AND DISCUSSION}

The impact of surface stormwater runoff on the state of natural water bodies is most pronounced in human settlements. Today, in cities, most of the surface runoff is collected in a stormwater system, and in natural reservoirs comes in the form of point sources. The surface runoffs are not always cleaned. The most common method of purification is sedimentation or separation processes whose main purpose is to clarify drains, to reduce the content of suspended matter in them.

The influence of stormwater runoff on surface water, in contrast to point sources such as discharges from factories and municipal wastewater treatment plants, is in most cases not so clear and significant. At the same time, if there are many recent works related to the influence of municipal wastewaters [Babko et al. 2016; Pliashechnyk et al. 2018, Majerek et al. 2019], then there are much fewer works related to the impact of stormwater runoffs.

Bioindication was conducted against the background of water quality assessment using chemical indicators such as $\mathrm{BOD}_{5}$ and COD. In the literature, there is a some of works relating to the assessment of water quality in the Bystrzyca river within the city of Lublin [Jaromin et al. 2012; Grzywna et al. 2016; Gorzel et al. 2018]. According to literature reports, the water quality studies in Bystrzyca conducted in 2016 indicated that in the segment below the Zemborzycki Lake, $\mathrm{BOD}_{5}$ reached the average value of $7.36 \mathrm{mgO}_{2} / 1$ at coefficient of variation of $10 \%$ [Grzywna et al. 2016], which is similar to the value obtained in this study. Slightly lower $\mathrm{BOD}_{5}$ values were observed by Gorzel et al. in the study on the Bystrzyca river tributaries, which was conducted in 2003-2004; the mean $\mathrm{BOD}_{5}$ values reached the level up to $6.1 \mathrm{mg} \mathrm{O}_{2} / 1$ [Gorzel et al. 2018]. In turn, on the basis of the research on chemical indicators determining the quality of water in the Parczew forests catchment area, the reported COD value in the summer period reaches 63-191 $\mathrm{mg} \mathrm{O}_{2} / 1$, while $\mathrm{BOD}_{5}-7-19 \mathrm{mg} \mathrm{O} / 1$. Simultaneously, it was observed that COD assumes the highest annual values in summer, whereas $\mathrm{BOD}_{5}$ - in spring (slightly lower $\mathrm{BOD}_{5}$ values are noted in summer) [Grzywna, 2014]. Similar values were observed by Janicka et al. [2017] while investigating the Bogdanka water course, in which the pollution level was rated as III-IV water purity class. The other work reported that the $\mathrm{BOD}_{5}$ values ranged from 5 to $7 \mathrm{mg} \mathrm{O}_{2} / 1$ while COD reached 40-50 $\mathrm{mg} \mathrm{O}_{2} / 1$ [Janicka et al. 2017].

High variability of chemical oxygen demand is connected with two cases related to the occurrence of relatively high COD values in storm water, equal to $170 \mathrm{mg} \mathrm{O}_{2} / 1$, which may indicate a large amount of pollutants accumulated in stormwater, especially considering that it rained, presumably contributing to washing the pollutants from the catchment and washing the substances in the drains. Additionally, as indicated in the literature, the storm waters, depending on the type and application of drained urban area, transmit significant amount of pollutants, i.e. total suspension, nitrogen compounds, heavy metals and crude oil derivatives [Joshi and Balasubramanian 2010, Gasperi et al. 2010, Jaromin-Gleń et al. 2012].

According to our measurements in point 1, $\mathrm{BOD}_{5}$ reached the value of $7.50 \mathrm{mg} \mathrm{O} / 1$ (standard deviation of 0.61 and coefficient of variation of $10 \%$ ), whereas COD assumed the mean value of approximately $55.00 \mathrm{mg} \mathrm{O} / 1$ (standard deviation of 6.47 and coefficient of variation of $17 \%$ ). In point 2 , i.e. storm wastewater discharge location, mean COD values of $82.50 \mathrm{mgO}_{2} / 1$ were observed, with standard deviation of 41.86 and coefficient of variation of about $60 \%$, whereas $\mathrm{BOD}_{5}$ reached $8.20 \mathrm{mg} \mathrm{O}_{2} / 1$ on average, with standard deviation of 0.58 and coefficient of variation amounting to $11 \%$. In turn, in point 3 where full mixing of river and stormwater occurred, lower 
$\mathrm{COD}$ and slightly higher $\mathrm{BOD}_{5}$ values were observed, reaching $62.50 \mathrm{mg} \mathrm{O}_{2} / 1$ and $7.67 \mathrm{mg} \mathrm{O}_{2} / 1$, respectively, which indicates a gradual return of water parameters to the state prior to wastewater discharge. The values of COD were characterized by $14 \%$ variability, which is much lower than in point 2 . The variability of biological oxygen demand was similar (approximately 11\%). The available research results pertaining to similar catchment areas indicate that the storm wastewater was characterized by COD in the range of $38-129 \mathrm{mgO}_{2} / 1$ and $\mathrm{BOD}_{5}$ reaching $10-45 \mathrm{mgO}_{2} / 1$ [Ociepa 2011]. These values are thus similar to the ones determined in point 2, as part of the investigations carried out as part of this work.

The effect of stormwater runoff on the river Bystrzyca (Lublin) was studied using bioindication method. The water quality was assessed based on the presence and abundance of algal speciesindicators from different systematic groups. The choice of the species-indicators did not depend on their systematic position, but was determined by their frequency of occurrence in the samples (the incidence is above 65\%) (Table 1).

Figure 1 presents the mean values of saprobity index in particular points under investigation. It was observed that in point 2 (wastewater discharge) the index value is the highest and reaches 2.09. In turn, in point 3 , where complete mixing of storm wastewater with river water occurred, the value of this index decreased, closing to the value in the reference (point 1), similarly as in the case of the results of physicochemical analyses of river water. Generally, the quality of water in the considered part of the Bystrzyca river corresponds to the $\beta$-mesosaprobic zone. In general,

Table 1. Algae species and their saprobic characteristics

\begin{tabular}{|l|c|c|}
\hline \multicolumn{1}{|c|}{ Species } & Saprobity & Index \\
\hline Achnanthes lanceolata & $x$ & 1.0 \\
\hline Cyclotella comta & o- $\beta$ & 1.5 \\
\hline Microspora amoeba & o- $\beta$ & 1.7 \\
\hline Nitzschia acicularis & $\alpha$ & 2.7 \\
\hline Pediastrum duplex & $\beta$ & 1.8 \\
\hline Pinnularia microstauron & o & 1.2 \\
\hline Rhoicosphenia curvata & $\beta$ & 2.0 \\
\hline Scenedesmus quadricauda & $\beta$ & 2.0 \\
\hline Synedra acus & $\beta$ & 2.0 \\
\hline Synedra ulna & $\beta$ & 2.0 \\
\hline Tabellaria flocculosa & $0-x$ & 1.1 \\
\hline Ulothrix tenuissima & $\beta$ & 2.1 \\
\hline
\end{tabular}

the saprobity index reached the mean values below 1.86 .

The specificity of algae as indicators is determined not only by water quality but also by the photic conditions. One of the factors negatively affecting natural water bodies is actually an increase in turbidity and the content of suspended matter. The decreasing of transparency usually leads to a decrease in the productivity of photosynthetics, which especially affects the green algae. The integral abundance of algae in the investigated points is shown in Figure 2. As can be seen from the figure, the maximum decrease in the number of algae was observed in the biofilms of the walls of the channel of the stormawter discharge. The tendency of reduction in the abundance of algae in the biofilms on the substrate was also kept after the runoff (Fig. 2).

As shown in Table 1, representatives of 6 saprobic groups are present among the species of algae. The data on their quantitative representation reflect their response to the conditions formed at each point. First of all, the composition of the biofilm (periphyton) on the walls of the channel (receiver) of effluent was quantitatively dominated by representatives of $\alpha$-saprobes. At the same time (Fig. 3A), their expected increase was observed below the inflow of the runoff, compared to the control point 1 , as well as the decrease in their abundance at point 3 compared to point 2 $\left(\mathrm{p}<10^{-7}\right)$; the differences between point 1 and 3 are not significant $(\mathrm{p}>0.05)$.

$\beta$-saprobes were quite abundant in all analysed points and there were no significant differences between points $(p>0.05)$ in respect to the representatives of this group (Fig. 3B). This indicates that the conditions in the river and in the drain as a whole correspond to the level of the $\beta$ zone. This explains the high abundances of $\beta$-saprobes at all points.

At the same time, the saprobic system for assessing the quality of natural waters is very approximate and reservoirs with very different conditions can get into the same saprobity zone. This is the result of the imperfection of the bioindication system due to the lack of detailed information on the physiology of species-indicators and their tolerance intervals.

On the other hand, at current stage, the express assessment according to the saprobic system allows only approximate characterization of the system and the results correspond to a wide range of its real states. It is obvious that all 


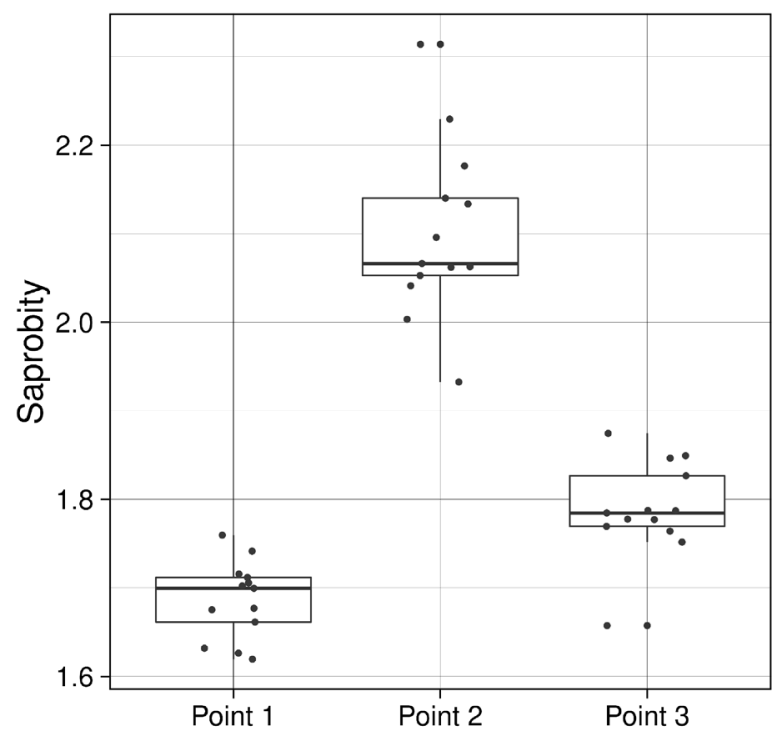

Figure 1. Values of saprobity at the studied sampling points

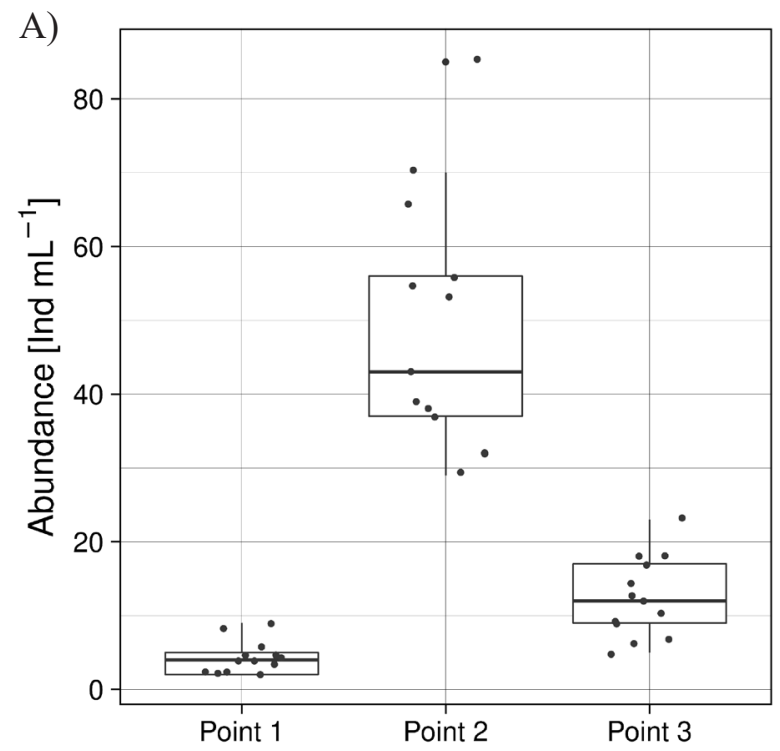

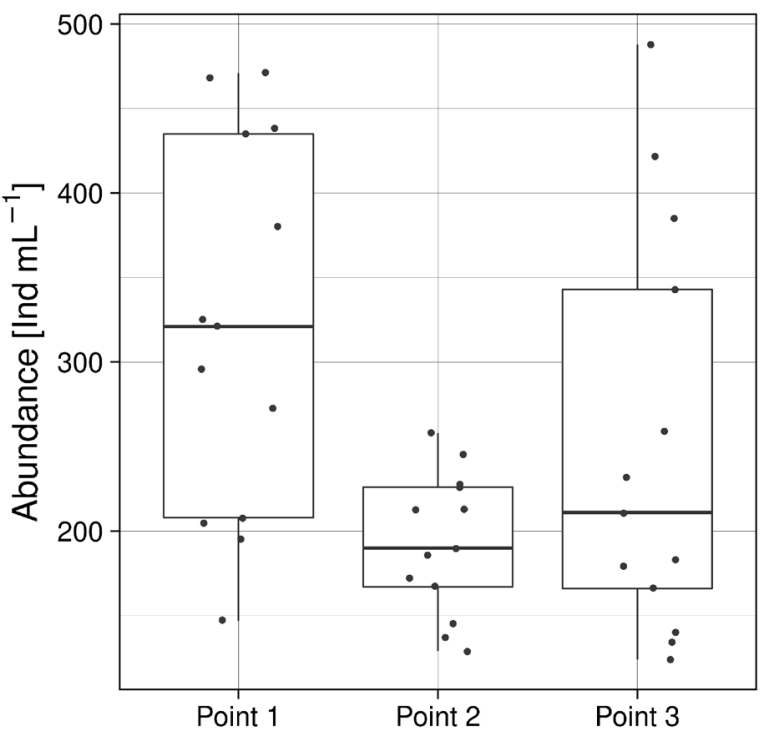

Figure 2. The total abundance of algae in biofilm samples at the studied points

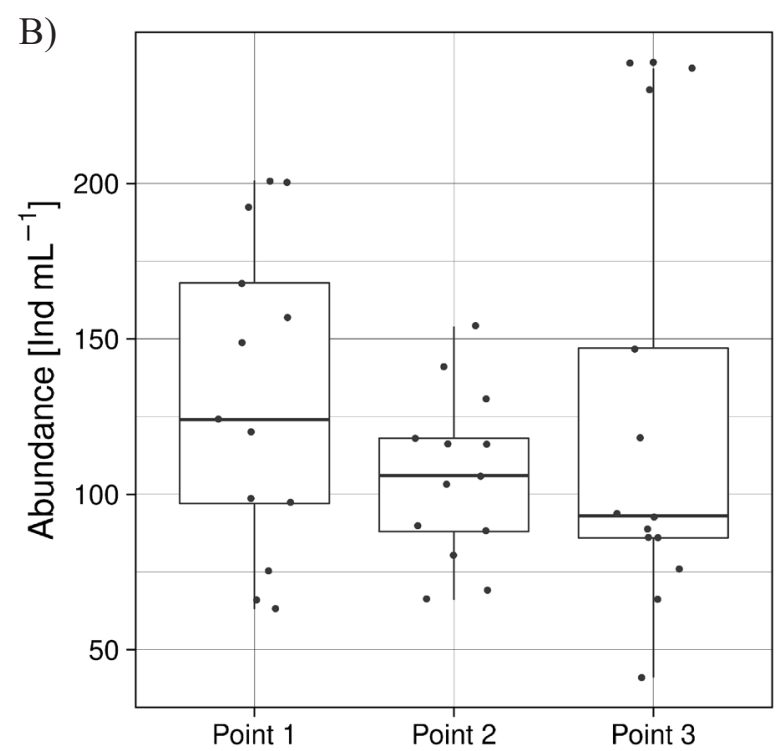

Figure 3. Distribution of (A) $\alpha$-saprobic and (B) $\beta$-saprobic species at points in the studied section of the river

representatives of oligo-, oligo-xeno and xenosaprobes did not disappear from the population of biofilms, but their number was critically low. At the same time, it is prominent that if beta-oligo saprobes, like beta-saprobes, were present in hundreds, then starting from oligosaprobes, their representation in the river was decreased to several dozen (below 30 ind. $\mathrm{ml}^{-1}$ ), and sporadic occurrences under runoff conditions $\left(<10\right.$ ind. $\left.\cdot \mathrm{ml}^{-1}\right)$.

In order to clarify the effect of wastewaters, we analysed the reaction of each of the present saprobic groups at each of the points, under, as was established, roughly $\beta$-mesosaprobic conditions.
Therefore, starting from beta-oligosaprobes, the situation regarding the quality of the environment at each of the points looks more differentiated. Beta-oligosaprobes were diminished in quantity under runoff conditions $\left(\mathrm{p}<10^{-5}\right)$ and had maximum development at point 1 (Fig. 4A). At point 3, their abundance was significantly lower compared to point $1(\mathrm{p}=0.02)$, but higher than at point $2(\mathrm{p}=0.015)$, obviously the effect of the runoff and it subsequent dilution.

The number of oligosaprobes at the runoff discharge point in comparison with the control point 1 decreased significantly $\left(\mathrm{p}<10^{-7}\right)$, approximately by 6-7 times (Fig. 4B). At the same time, 
the effect of runoff led to a twofold decrease in oligosaprobes abundances $(p<0.0004)$ in comparison with control point.

The reaction of oligo-xenosaprobes was not pronounced enough (Fig. 5A). Although their distribution among points corresponded to the general trend, nevertheless, their quantitative representation at all points was fairly close (mean while differences between points 1 and 2 are statistically significant, $p=0.015$ ). It is quite possible that this is a signal to clarify the saprobic characteristics of these species. At the same time, their low abundances show that $\beta$-saprobic conditions negatively affect their development.

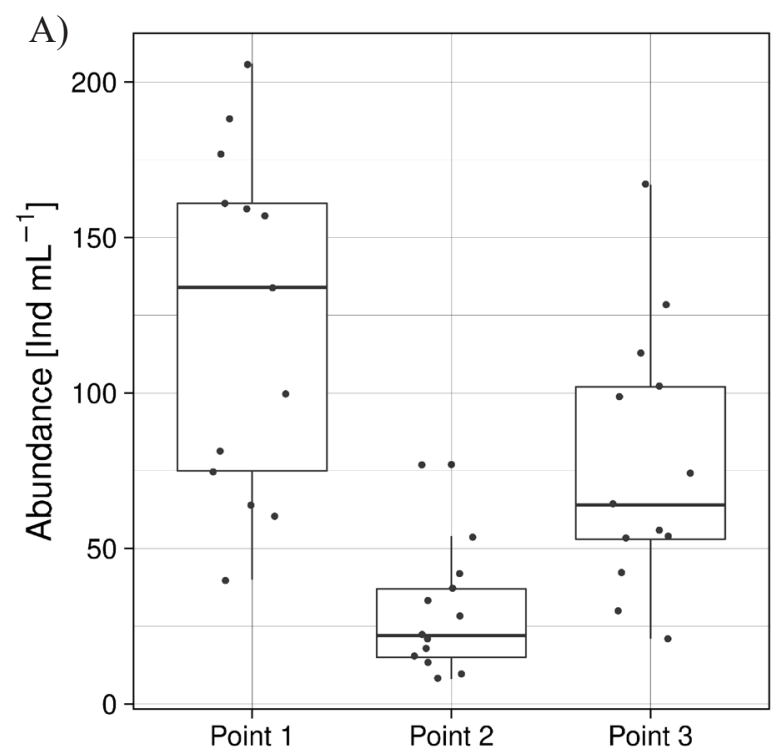

The xenosaprobic species showed a clear reaction to the runoff (Fig. 5B). All pairwise differences between points are significant $\left(p<10^{-7}\right)$. The abundance of xenosaprobes at the control point was approximately 5 times higher than in stock $\left(\mathrm{p}<10^{-7}\right)$. In turn, the effect of runoff on point 3 was expressed as the twofold reduction of xenosaprobes in the periphyton at point 3, compared to the control one.

The situation with the development of oligo, oligo-xeno and xenosaprobes looks quite logical from the point of view of the influence of drains. Therefore, the abundances of all the abovementioned groups at point 1 had the maximum

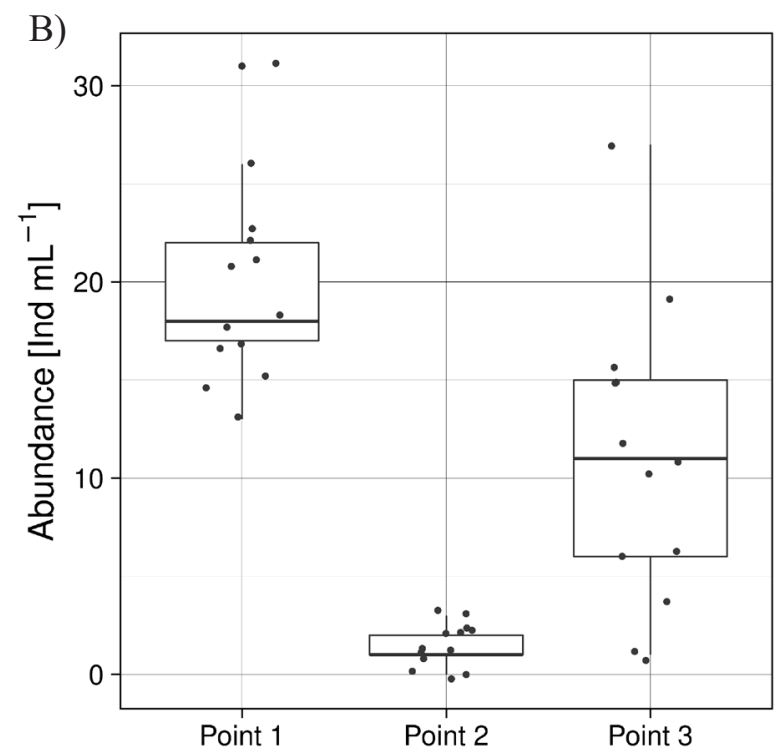

Figure 4. Distribution of (A) beta-oligosaprobic and (B) oligosaprobic species at points in the studied section of the river
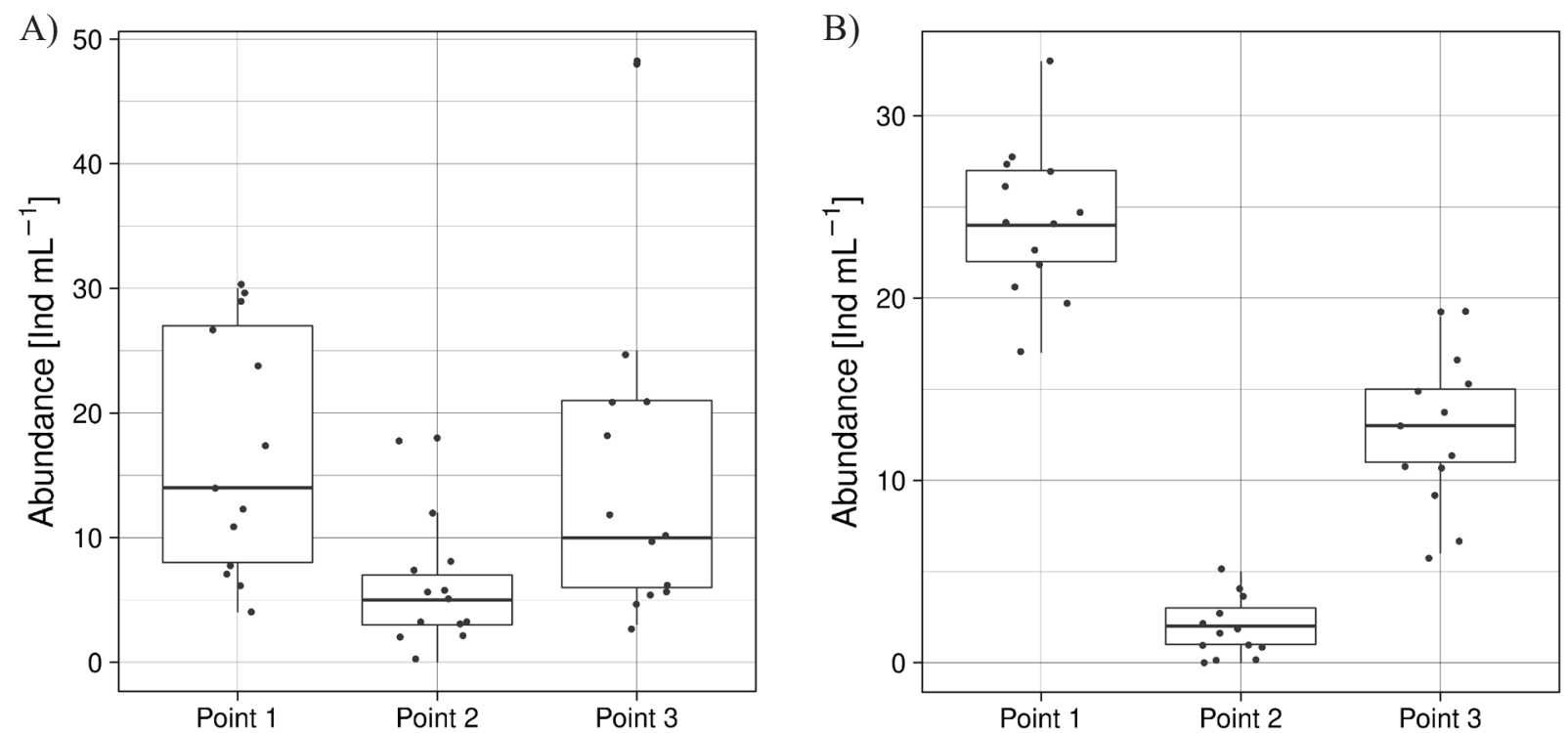

Figure 5. Distribution of (A) oligo-xenosaprobic and (B) xenosaprobic species at points in the studied section of the river 
values (Figs. 4B, 5A, B). At the same time, their abundance in conditions of runoff reached a minimum. The presence of these species at all points indicates that they can tolerate the betasaprobic conditions; however, on the other hand, they demonstrate a more subtle response within this roughly speaking saprobic zone, which enables a more detailed assessment of the level of environmental pollution.

\section{CONCLUSION}

The paper presents the results of bioindication studies pertaining to the influence of storm sewerage on the recipient, i.e. Bystrzyca river, in the area of Muzyczna street in Lublin, Poland. The obtained results of studies confirm the influence of storm water on the recipient waters, i.e. Bystrzyca river. The substances and pollutants transmitted to the river along with storm water noticeably impact the assemblage structure of the algae found in the river waters.

\section{REFERENCES}

1. Adamiec P. 2008. Wykorzystanie walorów przyrodniczo-krajobrazowych dolin rzecznych Lublina w rekreacji, Nauka Przyroda Technologie, 2(4), 47.

2. Babko R., Kuzmina T., Suchorab Z., Widomski M.K., Franus M. 2016. Influence of treated sewage discharge on the benthos ciliate assembly in the lowland river. Ecological Chemistry and Engineering S, 23(3), 461-471.

3. Carter J.L., Resh V.H., Hannaford M.J., Myers M.J. 2006. Macroinvertebrates as biotic indicators of environmental quality. In: Hauer FR, Lamberti GA, editor. Methods in Stream Ecology. Amsterdam: Academic Press, 2006, 805-833.

4. Chomczyńska M., Montusiewicz A., Malicki J., Łagód G. 2009. Application of Saprobes for Bioindication of Wastewater Quality. Environmental Engineering Science, 26(2), 289-295.

5. Desrosiers C., Leflaive J., Eulin A., Ten-Hagea L. 2013. Bioindicators in marine waters: Benthic diatoms as a tool to assess water quality from eutrophic to oligotrophic coastal ecosystems, Ecological Indicators, 32, 25- 34.

6. Gasperi J., Gromaire M.C., Kafi M., Moilleron R., Chebbo G. 2010. Contributions of wastewater, runoff and sewer deposit erosion to wet weather pollutant loads in combined sewer system. Water Research, 44, 5875-5886.
7. Gorzel M., Kornijow R. 2007. The response of zoobenthos to „natural channelization” of a small river. Ecohydrology and Hydrobiology, 7(1), 59-70.

8. Gorzel M., Kornijów R., Buczyńska E. 2018. Quality of rivers: comparison of hydro-morphological, physical-chemical and biological methods. Ecological Chemistry and Engineering. S, 25(1), 101-122.

9. Gray N.F., Delaney E. 2010. Measuring community response of bentic macroinvertebrates in an erosional river impacted by acid mine drainage by use of a simple model. Ecological Indicators, 10, 668-675.

10. Grzywna A. 2014. Chemical water quality indicators in basin forest Parczew. Ecological Engineering, 36, 120-127.

11. Grzywna A., Jóźwiakowski K., Gizińska-Górna M., Marzec M., Mazur A., Obroślak R. 2016. Analysis of ecological status of surface waters in the Bystrzyca river in Lublin. Journal of Ecological Engineering, 17(5), 203-207.

12. Gücker B., Brauns M., Pusch M.T. 2006. Effects of wastewater treatment plant discharge on ecosystem structure and function of lowland streams. Journal of the North American Benthological Society, 25, 313-329.

13. Iliopoulou-Georgudaki J., Kantzaris V., Katharios P., Kaspiris P., Georgiadis Th., Montesantou B. 2003. An application of different bioindicators for assessing water quality: a case study in the rivers Alfeios and Pineios (Peloponnisos, Greece). Ecological Indicators, 2, 345-360.

14. Janicka E., Kanclerz J., Borowiak K., Wiatrowska K., Lisiak M. 2017. Quality water in bogdanka stream. Ecological Engineering, 18 (1), 202-208.

15. Jaromin K.M., Girol A., Głowienka R., Łagód G. 2012. Jakość ścieków deszczowych wybranego kolektora zbiorczego miasta Lublin na tle jakości wód odbiornika - rzeki Bystrzycy. Inżynieria Środowiska - Młodym Okiem, 1, 247-251

16. Jaromin-Gleń K.M., Widomski M.K., Łagód G., Mazurek W. 2012. Concentrations of pollutants in storm wastewater for selected catchment in Lublin, Poland. Proceedings of ECOpole 2012, 6(2).

17. Joshi U.M., Balasubramanian R. 2010. Characteristics and environmental mobility of trace elements in urban runoff. Chemosphere, 80, 310-318.

18. Kolkwitz R., Marsson K. 1908. Ökologie der pflanzlichen Saprobien Ber. dt. bot. Ges., 26A, 505-519.

19. Kolkwitz R., Marsson K. 1909. Ökologie der tierischen Saprobien Int. Revue ges. Hydrobiol. Hydrogr., 2, 126-152.

20. Kolkwitz R. 1950. Ökologie der Saprobien SchReihe Ver. Wass. Boden - u. Lufthyg. 4, 1-64.

21. Kominkova D., Stransky D., St'astna G., Caletkova J., Nabelkova J., Handova Z. 2005. Identifica- 
tion of ecological status of stream impacted by urban drainage. Waterer Science and Technology, 51(2), 249-256.

22. Konstantinov A.S. 1979. Obshchaya hydrobiologia. M. Vysshaya shkola.

23. Lane C.R., Brown M.T. 2007. Diatoms as indicators of isolated herbaceous wetland condition in Florida, USA. Ecological Indicators, 7, 521-540.

24. Li L., Zheng B., Liu L.. 2010. Biomonitoring and Bioindicators Used for River Ecosystems: Definitions, Approaches and Trends, Procedia Environmental Science, 2, 1510-1524.

25. Libudzisz Z., Kowal K., Żakowska Z. 2007. Mikrobiologia techniczna - tom 1 , Wydawnictwo Naukowe PWN, Warszawa.

26. Łagód G., Malicki J., Chomczyńska M., Montusiewicz A. 2007. Interpretation of the results of wastewater quality biomonitoring using saprobes. Environmental Engineering Science, 24(7), 873-879.

27. Majerek D., Duda S., Babko R., Widomski M.K. 2019. Statistical analysis of the water pollution indicators pertaining to treated municipal sewage introduced to the river. MATEC Web of Conferences 252, 09009,

28. Ociepa E. 2011. Ocean zanieczyszczenia ścieków deszczowych trafiających do kanalizacji deszczowej. Inżynieria i Ochrona Środowiska, 14(4), 357-364.

29. Pantle R., Buck H. 1955. Die Biologische Überwachung der Gewässer und die Darstellung der Ergebnisse. Gas und Wasserfach, 96(18), 604.

30. Pantle R. 1956. Biologische Flussuberwachung. Wasserwirtschaft, 46(8), 206-209.

31. Pliashechnyk V., Danko Y., Łagód G., Drewnowski J., Kuzmina T., Babko R. 2018. Ciliated protozoa in the impact zone of the Uzhgorod treatment plant. E3S Web of Conferences, 30 (02008), 1-7.
32. R Core Team, 2019. R: A language and environment for statistical computing. R Foundation for Statistical Computing, Vienna, Austria. https:// www.R-project.org/.

33. Sladeček V. 1973. System of water quality from the biological point of view. Arch. Hydrobiol. Beih. Ergebn. Limnol., 7(7), 1-218.

34. Smith V.H., Tilman G.D., Nekola J.C. 1999. Eutrophication: impacts of excess nutrient inputs on freshwater, marine, and terrestrial ecosystems. Environmental Pollution, 100 (1-3), 179-196.

35. Spänhoff B., Bischof R., Böhme A., Lorenz S., Neumeister K., Nöthlich A., Küsel K. 2007. Assessing the impact of effluents from a modern wastewater treatment plant on breakdown of coarse particulate organic matter and benthic macroinvertebrates in a lowland river. Water, Air, \& Soil Pollution, 180, 119-129.

36. Wakelin S.A., Colloff M.J., Kookana R.S. 2008. Assessing the effect of wastewater treatment plant effluent on microbial function and community structure in the sediment of a freshwater stream with variable seasonal flow. Applied and Environmental Microbiology, 74, 2659-2668.

37. Wickham H. 2009. ggplot2: elegant graphics for data analysis. Springer New York.

38. Wright I.A., Chessman B.C., Fairweather P.G., Benson L.J. 1995. Measuring the impact of sewage effluent of an upland stream: the effect of different levels of taxonomic resolution and quantification. Australian Journal of Ecology, 20, 142-149.

39. Żbikowski R., Szefer P., Latała P. 2007. Comparison of green algae Cladophora sp. and Enteromorpha sp. as potential biomonitors of chemical elements in the southern Baltic. Science of The Total Environment, 387, 320-332. 